\title{
Pelatihan Pembuatan Alat Peraga Matematika bagi Guru-guru SD YPK Yoka Baru Waena Kota Jayapura
}

\author{
${ }^{1}$ Ronaldo Kho, ${ }^{2}$ Dewi Kristika N. Tyas \\ Univeristas Cenderawasih \\ ronaldoankho@gmail.com
}

\begin{abstract}
Abstrak. Untuk mengajar matematika khususnya konsep pecahan kepada siswa sekolah dasar, guru dituntut harus menyiapkan strategi yang jitu agar siswa dengan mudah memahami materi yang diajarkan. Salah satu strategi yang dapat digunakan oleh guru adalah menerapkan pembelajaran Joyful learning dengan memanfaatkan media pembelajaran berupa alat peraga. Kegiatan pengabdian ini dilaksanakan dengan tujuan untuk meningkatkan kemampuan guru-guru SD YPK Yoka Baru Waena Kota Jayapura dalam merancang, membuat, dan menggunakan alat peraga dalam pembelajaran matematika khususnya alat peraga roda pecahan. Hasil pengabdian menunjukkan bahwa (1) Pelaksanaan kegiatan berjalan dengan lancar, (2) Tidak semua peserta mampu memahami pembuatan alat peraga roda pecahan, dan (3) Guru/peserta dapat memahami terhadap cara penggunaan alat peraga roda pecahan dalam pembelajaran pecahan melalui kelas simulasi.
\end{abstract}

Kata kunci: Alat peraga, Joyful learning

\section{PENDAHULUAN}

Latar belakang

Matematika adalah salah satu disiplin ilmu yang banyak digunakan untuk menunjang perkembangan lima pengetahuan dan teknologi dan juga digunakan dalam kehidupan sehari-hari. Melihat betapa pentingnya matematika, sehingga matematika perlu diajarkan mulai dari jenjang pendidikan dasar hingga pendidikan menengah, bahkan digunakan di jenjang pendidikan tinggi. Matematika yang diajarkan di jenjang persekolahan disebut matematika sekolah. Menurut R. Soedjadi (2000), matematika sekolah adalah unsur-unsur matematika yang dipilih guna menunjang perkembangan ilmu pengetahuan dan teknologi dan disesuaikan dengan perkembangan intelektual siswa.

Melihat betapa pentingnya matematika perlu dipelajari, tetapi di lain sisi matematika memuat objek-objek kajian yang abstrak berupa fakta, konsep, prinsip, ataupun skill. Sehingga di jenjang persekolahan, banyak siswa mengalami kesulitan dalam memahami objek-objek matematika. Terdengar suarasuara dalam kehidupan sehari-sehari yang dikeluhkan oleh orang tua siswa maupun siswa itu sendiri bahwa matematika merupakan mata pelajaran yang sulit. Banyak orang yang alergi terhadap matematika.
Upaya-upaya yang telah dilakukan oleh pemerintah dengan berbagai strategi pembelajaran, pendekatan pembelajaran, model pembelajaran, model mengajar, ataupun teknik mengajar yang telah diberikan kepada guru-guru matematika melalui pelatihanpelatihan. Dengan harapan agar guru mampu mengajarkan matematika dengan suasana menyenangkan sehingga siswa dapat memahami materi yang diajarkan. Upayaupaya tersebut masih saja terhadang oleh keluhan-keluhan siswa tentang matematika sulit dipelajari.

Pantauan juga terhadap guru-guru SD yang mengikuti Pendidikan dan Latihan Profesi Guru (PLPG) tahun 2011 sampai dengan 2016 memperlihatkan bahwa hampir sebagian besar guru mengatakan bahwa mereka mengalami kesulitan dalam mengajarkan mata ajar matematika. Hasil pengamatan di SD YPK Yoka Baru Waena Kota Jayapura juga dijumpai keluhan para guru bahwa banyak siswa sulit mempelajari matematika. Hal ini dapat dilihat dari hasil belajar pada mata pelajaran matematika belum mencapai nilai KKM (kriteria ketuntasan mengajar).

Salah satu cara yang perlu dilakukan oleh guru adalah membuat pembelajaran menyenang. Model pembelajaran yang turut 
membuat suasana pembelajaran menyenangkan adalah joyful learning. Teknik penyampaian materi matematika melalui penerapan model pembelajaran joyful learning adalah menggunakan alat peraga. Dalam pembelajaran joyful learning, siswa terlibat dalam suasana permainan sambil belajar matematika dengan memanfaatkan alat peraga matematika.

Kenyataan di lapangan menunjukkan bahwa banyak sekolah dasar termasuk di SD YPK Yoka Baru Waena Kota Jayapura yang belum cukup mempunyai alat peraga matematika untuk melaksanakan pembelajaran joyful learning. Di satu sisi guru juga belum terlatih atau tidak sama sekali dalam pembuatan alat peraga yang tepat untuk digunakan dalam pembelajaran matematika di kelas.

\section{Tujuan Kegiatan}

Tujuan yang ingin dicapai melalui pengabdian adalah meningkatkan kemampuan guru•-guru SD YPK Yoka Baru Waena Kota Jayapura dalam merancang, membuat, dan menggunakan alat peraga dalam pembelajaran matematika.

\section{Manfaat Kegiatan}

Hasil kegiatan pengabdian ini memberi kontribusi bekal tambahan pengetahuan bagi guru SD YPK Yoka Baru Waena Kota Jayapura berupa kemampuan merancang dan membuat alat peraga sederhana serta keterampilan dalam memilih dan menggunakar alat peraga yang digunakan dalam pembelajaran matematika di kelas. Diharapkan juga pengalaman yang diperoleh dapat ditularkan kepada guru SD yang lain. Di samping itu terdapat manfaat bagi program studi pendidikan matematika adalah terjalin kerjasama yang mutualistis antara Uncen (Program studi pendidikan matematika) dengan sekolat dasar YPK Yoka Baru Waena Kota Jayapura dalam upaya pembenahan dan peningkatan kualitas pemahaman siswa terhadap fakta, konsep, prinsip, dan skill matematika. Serta dapat menerapkan matematika dalam kehidupan sehari-hari.

\section{KAJIAN PUSTAKA Joyful Learning}

Wei, et al. (2011) mendefinisikan Joyful learning sebagai suatu proses pembelajaran atau pengalaman belajar yang membuat siswa merasa senang dalam skenario belajar atau proses pembelajaran. Joyful learning dapat membantu mengembangkan kemampuan berpikir, membangun sendiri konsep materi pelajaran serta kemampuan merumuskan simpulan. Juga melalui joyful learning siswa dihadapkan kepada suatu keadaan yang menyenangkan sehingga dapat membuat siswa menyukai materi yang diberikan karena proses belajar dirancang lebih dinamis serta menekankan pada hal-hal visual dan menyenangkan

Langkah-langkah proses belajar mengajar dengan pendekatan joyful learning adalah:

a. Guru menjelakan materi pelajaran dengan metode ceramah dan tanya jawab.

b. Siswa dibagi menjadi beberapa kelompok kecil 4-5 orang dan diberi soal latihan untuk disesuaikan pada waktu itu juga.

c. Setelah selesai mengerjakan soal tersebut, siswa disuruh mendemonstrasikan di depan kelas.

d. Cara menunjuk siswa untuk mengerjakan di depan dengan cara permainan.

e. Siswa menyimpulkan materi yang dipelajari.

f. Guru menyempurnakan simpulan yang telah diperoleh dari siswa dan memberikan penghargaan kepada siswa yang berani mendemonstrasikan jawaban ke depan kelas.

Dengan demikian pembelajaran matematika dengan joyful learning dapat meningkatkan keaktifan belajar siswa dan dapat mengembangkan pengetahuan, sikap, nilai, dan perilaku yang bertanggung jawab terhadap lingkungan sekitar.

\section{Alat Peraga Matematika}

Djoko Iswadji (2003) menyatakan bahwa alat peraga matematika adalah seperangkat benda konkret yang dirancang, dibuat, dihimpun atau disusun secara sengaja yang digunakan untuk membantu menanamkan atau 
mengembangkan konsep-konsep atau prinsip-prinsip dalam matematika. Dengan alat peraga, hal-hal yang abstrak dapat disajikan dalam bentuk modelmodel yang berupa benda konkret yang dapat dilihat, dipegang, diputarbalikkan sehingga dapat lebih mudah dipahami. Fungsi utamanya adalah untuk menurunkan keabstrakan konsep agar siswa mamapu menangkap arti konsep tersebut. Sebagi contoh, benda-benda konkret di sekitar siswa seperti buahbuahan, pensil, buku, dan sebagainya. Dengan benda-benda tersebut siswa dapat membilang banyaknya anggota dari kumpulan suatu benda sampai menemukan bilangan yang sesuai pada akhir membilang. Contoh lainnya, modelmodel bangun datar, bangun ruang, dan sebagainya.

Dari segi pengadaannya alat peraga dapat dikelompokkan sebagai alat peraga sederhana dan alat peraga buatan pabrik. Pembuatan alat peraga sederhana biasanya memanfaatkan lingkungan sekitarnya dan dapat dibuat sendiri. Sedangkan alat peraga buatan pabrik pada umumnya berupa perangkat keras dan lunak yang pembuatannya memeliki ketelitian ukuran serta memerlukan biaya yang tinggi.

Model alat peraga yang akan dirancang, dibuat, dan digunakan adalah: Alat peraga roda pecahan yang digunakan untuk mempermudah pembelajaran pengertian pecahan, penjumlahan dua pecahan, perkalian dua pecahan, kesamaan dua pecahan.

Adapun metode pelaksanaan kegiatan pengabdian dilakukan melalui langkahlangkah sebagai berikut:

1. Membuat desain/rancangan alat peraga yang dibutuhkan.

2. Menyusun modul materi pelatihan.

3. Melaksanakan pelatihan sesuai jadwal yang ditentukan.

4. Guru-guru yang telah dilatih akan mulai menggunakan alat peraga dalam pembelajaran matematika di kelas.

5. Memonitoring pelaksanaan penggunaan alat peraga oleh guru dalam pembelajaran matematika di kelas.
6. Di akhir program pengabdian, diadakan evaluasi secara keseluruhan untuk mengetahui tingkat keberhasilan program pelatihan.

Secara ringkas langlah-langkah pelaksanaan kegiatan pengabdian digambarkan dalam Gambar 1 berikut.

Gambar 1 Kerangka Metode Kegiatan

\begin{tabular}{|c|c|c|c|}
\hline $\begin{array}{l}\text { PERSIAPAN } \\
\text { KEGIATAN }\end{array}$ & PELATIHAN & IMPLEMENTASI & $\begin{array}{l}\text { EVALUASI } \\
\text { DROGRAM }\end{array}$ \\
\hline $\begin{array}{l}\text { - Membuat } \\
\text { desain alat } \\
\text { peraga } \\
\text { Menyusun } \\
\text { modul } \\
\text { pelatihan }\end{array}$ & $\begin{array}{l}\text { Sesi I: } \\
\text { Pemanfaatan } \\
\text { alat peraga } \\
\text { dalam } \\
\text { pembelajaran } \\
\text { matematika } \\
\text { dikelas } \\
\text { Sesi II: } \\
\text { Merancang } \\
\text { dan membuat } \\
\text { alat peraga } \\
\text { matematika } \\
\text { Sesi III: }\end{array}$ & $\begin{array}{l}\text { - Penerapan hasil } \\
\text { pelatihan pada } \\
\text { pembelajaran } \\
\text { matematika di } \\
\text { kelas } \\
\text {-Monitoring dan } \\
\text { evaluasi }\end{array}$ & $\begin{array}{l}\text { Evaluasiakhir } \\
\text { program untuk } \\
\text { mengetahui } \\
\text { tingkat } \\
\text { keberhasilan } \\
\text { program secara } \\
\text { menyeluruh }\end{array}$ \\
\hline
\end{tabular}

Evaluasi kegiatan dilaksanakan pada awal kegiatan, pada saat kegiatan, dan setelah kegiatan. Berikut ini diuraikan rancangan evaluasi pelatihan yang dilakukan tertera pad Tabel 1 berikut.

Tabel 1 Rancangan Evaluasi

\begin{tabular}{|l|l|l|r|}
\hline NO & \multicolumn{1}{|c|}{ KRITERIA } & \multicolumn{1}{|c|}{ INDIKATOR } & TARGET \\
\hline 1 & $\begin{array}{l}\text { Kesiapan materi pelatihan } \\
\text { (modul, slide presentasi) }\end{array}$ & $\begin{array}{l}\text { Semua materi pelatihan telah } \\
\text { tersedia }\end{array}$ & $100 \%$ \\
\hline 2 & $\begin{array}{l}\text { Pemahaman terhadap pembuatan alat } \\
\text { peraga matematika }\end{array}$ & $\begin{array}{l}\text { Semua peserta } \\
\text { mampu membuat } \\
\text { alat peraga }\end{array}$ & $100 \%$ \\
\hline 3 & $\begin{array}{l}\text { Pemahaman terhadap cara } \\
\text { menggunakan alat peraga matematika } \\
\text { dalam pembelajaran matematika } \\
\text { melalui kelas simulasi }\end{array}$ & $\begin{array}{l}\text { Banyaknya peserta mampu } \\
\text { mengajar dengan } \\
\text { menggunakan alat peraga } \\
\text { matematika dalam } \\
\text { pembelajam matematika }\end{array}$ & $90 \%$ \\
\hline
\end{tabular}

\section{PEMBAHASAN \\ DAN}

\section{PENELITIAN}

Pelaksanaan kegiatan pengabdian di SD YPK Yoka Baru Waena adalah sebagai berikut.

1. Pada kegiatan pertama, dilakukan penjelasan tentang joyful learning dan pemanfaatan alat peraga dalam pembelajaran matematika. Dilanjutkan dengan penjelasan tentang merancang dan membuat alat peraga roda pecahan.

2. Pada kegiatan kedua, dilakukan penjelasan dan simulasi penggunaan alat peraga roda pecahan.

3. Pada kegiatan ketiga, dilakukan penggunaan alat peraga roda pecahan dalam pembelajaran pecahan di kelas. 
Berdasarkan pelaksanaan kegiatan, dilakukan evaluasi akhir program untuk mengetahui tingkat keberhasilan secara penyeluruh. Hasil evaluasi menunjukkan bahwa:

1. Semua materi pelatihan telah tersedia.

2. Tidak semua peserta mampu memahami pembuatan alat peraga roda pecahan.

3. Guru/peserta dapat memahami terhadap cara penggunaan alat peraga roda pecahan dalam pembelajaran pecahan melalui kelas simulasi.

Melihat bahwa hasil kegiatan pengabdian dilaksanakan berjalan dengan lancar, akan tetapi masih perlu dilakukan pembenahan pada media alat peraga roda pecahan agar lebih sempurna dari segi ketepatan alat dan efisiensi alat. Dengan demikian pada kegiatan pengabdian berikutnya perlu didesain penyempurnan alat peraga roda pecahan.

\section{Foto-foto kegiatan}
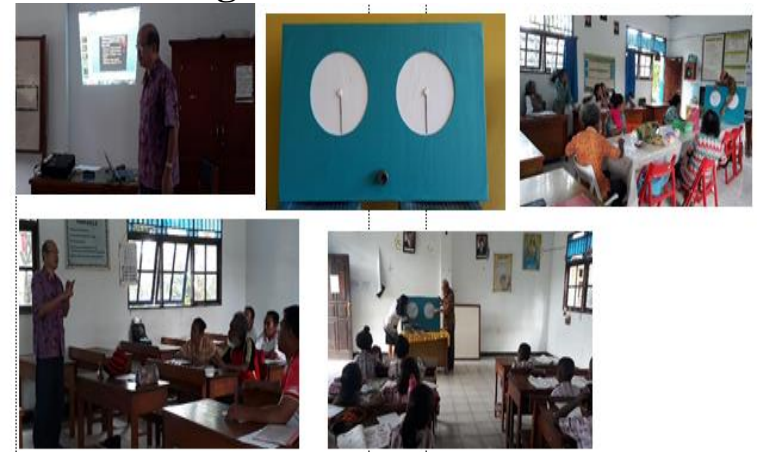

\section{SIMPULAN DAN SARAN}

Berdasarkan hasil pelaksanaan kegiatan, dapat disimpulkan bahwa

1. Pelaksanaan kegiatan berjalan dengan lancar.

2. Tidak semua peserta mampu memahami pembuatan alat peraga roda pecahan.

3. Guru/peserta dapat memahami terhadap cara penggunaan alat peraga roda pecahan dalam pembelajaran pecahan melalui kelas simulasi.

Melihat peranan alat peraga untuk mempermudah siswa memahami konsepkonsep dalam matematika, sehingga perlu dikembangkan jenis media alat peraga lain yang disesuaikan dengan kondisi siswa dan tingkat kematangannya.

\section{DAFTAR PUSTAKA}

Djoko Iswadji. 2003. Pengembangan Media Pembelajaran Matematika di SLTP. Yogyakarta: FMIPA UNY

R. Soedjadi. 2000. Kiat Pendidikan Matematika di Indonesia, Konstatasi Masa Kini Menuju Harapan Masa Depan. Jakarta: Dirjen Dikti. Depdiknas.

Wei, C., Hung, I., Lee, L. , Chen, N. 2011. The Turkish Online Journal of Educational Technology. 10(2), 11 23. 